УДК 342.95:347.962:336.225.611

DOI https://doi.org/10.32849/2663-5313/2021.3.25

\title{
Яна Бенедик,
}

канд. юрид.наук,

асистент кафедри порівняльного і європейського права

Інституту міжнародних відносин

Київського начіонального університету імені Тараса Шевченка

\section{Василь Бенедик,}

канд. юрид. наук, старший науковий співробітник, науковий консультант судді Конституиійного Суду Украйни

\section{ЗАРУБІЖНИЙ ДОСВІД ФОРМУВАННЯ СИСТЕМ ДЕКЛАРУВАННЯ СТАТКІВ СУДДЯМИ}

У статті досліджується досвід побудови систем декларування статків суддями в наиіональних правопорядках окремих, переважно європейських, держав. Основну увагу приділено чотирьом ключовим проблемам: а) запровадженню системи декларування для суддів як специфічних суб'єктів; b) порядку оприлюднення та режиму доступу до інформащії, що міститься в деклараціях суддів; c) системі інститутів, уповноважених здійснювати збір і перевірку декларачій суддів; $d$ ) юридичній відповідальності за неподання декларачій або зазначення недостовірної інформачій в них. Робиться низка висновків: у державах, яким притаманні значні показники розвитку й стабільності функиіонування демократичних інститутів, спеціальні законодавчі вимоги стосовно обов'язкового декларування статків суддями та відповідне інституиійне забезпечення переважно відсутні; у країнах, де такий обов'язок установлено, декларування суддями здійснюється або за загальними правилами, або відповідно до визначених спеиіальними законами правил і процедур, які можуть відрізнятися від загальних з огляду на специфічний статус суддів; $у$ більшості досліджуваних держав декларачї суддів знаходяться у відкритому доступі та зазвичай публікуються на спечіальних онлайн платформах, хоча в окремих випадках доступ до відповідної інформачї може надаватися тільки на підставі мотивованих запитів защікавлених осіб. Звертається увага на те, що залежно від специфіки інституиійного механізму системи декларування досліджувані держави можна поділити на три групи: ті, у яких акумулювання та перевірка деклараиій суддів здійснюється органами суддівського врядування, їх спеиіальними підрозділами; ті, де воно здійснюється в межах системи суиільного декларування статків державними службовиями - єдиним контролюючим антикорупиійним i/або податковим органом; ті, де воно здійснюється спільними зусиллями органів судового врядування й антикорупиійними, податковими або іншими уповноваженими органами. Також більшість держав тяжіє до криміналізації порушень правил і процедур декларування статків державними службовиями загалом і суддями зокрема.

Ключові слова: державний контроль, системи декларування статків, декларування статків суддями, зарубіжний досвід.

Постановка проблеми. Протягом майже всього періоду незалежності України питання запобігання корупції та боротьби з корупцією було й залишається одним із головних на порядку денному політико-правового та наукового дискурсів. У цьому контексті, як відносно новий інститут національного права, декларування статків державних службовців, закономірно посідає чільне місце серед інструментів запобігання й виявлення корупції та конфлікту інтересів. Наявні дослідження у відповідній сфері переважно концентруються на механізмах контролю стосовно виконавчої та законодавчої гілок влади. При цьому сьогодні детальні дослідження особливостей механізмів декларування стат- ків щодо суддів, запроваджені в різних національних юрисдикціях, $є$ нечисленними.

Метою статті є ідентифікація та аналіз
наявних світових практик формування
й функціонування систем декларування
статків суддями, іх інституційного забез-
печення, виокремлення іх особливостей
і проведення відповідної класифікації.

Виклад основного матеріалу. Загалом механізми декларування статків державних службовців, інкорпоровані в низку міжнародно-правових інструментів, є розповсюдженими в численних національних правопорядках і визнаються як ключовий інструмент забезпечення прозорості й під- 
звітності органів державної влади, запобігання корупції та боротьби з нею [1, с. 1].

Запровадження механізмів розкриття інформації щодо статків державних службовців набуло особливо значного поширення в національних правопорядках протягом останніх трьохдесятиліть. Цьому, середіншого, сприяло прийняття у 2003 році Конвенції ООН проти корупції [2], частина 5 статті 8 якої встановлює, що «кожна Держава-учасниця прагне, у належних випадках і згідно з основоположними принципами свого внутрішнього права, запроваджувати заходи й системи, які зобов'язують державних посадових осіб надавати відповідним органам декларації, серед іншого, про позаслужбову діяльність, заняття, інвестиції, активи та про суттєві дарунки або прибутки, у зв'язку з якими може виникнути конфлікт інтересів стосовно їхніх функцій як державних посадових осіб».

Також «кожна Держава-учасниця розглядає можливість створення, відповідно до свого внутрішнього права, ефективних систем, які передбачають розкриття фінансової інформації щодо відповідних державних посадових осіб, і встановлює відповідні санкції за недотримання цих вимог. Кожна Держава-учасниця також розглядає можливість ужиття таких заходів, які можуть бути необхідними, щоб дозволити своїм компетентним органам здійснювати обмін такою інформацією 3 компетентними органами інших Держав-учасниць, якщо це необхідно для розслідування, заявлення прав і вжиття заходів щодо повернення доходів, здобутих злочинним шляхом, визначених цією Конвенцією» (частина 5 статті 52 Конвенції).

Крім цього, регіональні міжнародні договори закріплюють еквівалентні зобов'язання, адресовані державам-учасницям (наприклад, Конвенція Африканського Союзу щодо запобігання та протидії корупції [3] стаття 7, Арабська конвенція проти корупції [4] - стаття 28, Міжамериканська конвенція проти корупції [5] - стаття III).

Незважаючи на те що, як демонструють численні дослідження у сфері декларування статків посадовими особами органів законодавчої та виконавчої влади, базовою метою реалізації відповідних інструментів є забезпечення загальної культури доброчесності, безпосередні цілі імплементації таких ініціатив є специфічними для кожної держави, що зумовлює особливості правового й інституційного механізмів, упроваджених для їх досягнення на національному рівні. У відповідних державах орган, уповноважений забезпечувати збір та управління інформацією про майно й доходи посадових осіб, як правило, має автономний статус і наділений мандатом на здійснення антикорупційної діяльності або аудиторського (фінансового) контролю [1, с. 3].

Водночас, якщо вести мову про суддів як державних службовців зі спеціальним статусом зі змісту Висновку № 21 (2018) Консультативної ради європейських суддів (КРСС) «Про запобігання корупції серед суддів», можна зробити висновок, що надійна система декларування статків може сприяти виявленню та подальшому уникненню конфлікту інтересів, отже, слугувати більшій прозорості судової системи та підтримці загальної атмосфери доброчесності суддів [6, para. 39].

Однак, ураховуючи право судді на приватне життя та право на приватність членів його сім'ї, упровадження відповідної системи має суворо відповідати принципу пропорційності. Першим елементом останнього є питання необхідності. У багатьох державах-членах Ради Європи, де корупція не $є$ проблемою, не видається необхідним запровадження обов'язкової системи декларування статків [6, para. 40]. Крім того, навіть у країнах, де існує система декларування майна й доходів, належну увагу завжди варто приділяти пропорційності заходів, опосередкованих функціонуванням відповідної системи. Розкриття інформації зацікавленим сторонам, що не належать до судової влади, має здійснюватися лише за умови наявності достовірних і законних підстав. При цьому конфіденційна інформація ніколи не повинна розголошуватися, а приватність третіх осіб, таких як члени сім'ї судді, повинна базуватися на додаткових гарантіях, порівняно 3 тими, що мають бути забезпечені самим суддям [6, para. 41].

У цьому контексті визначення особливостей функціонування системи декларування статків для суддів логічно потребуе висвітлення низки специфічних аспектів: a) чи $є$ такий механізм настільки ж розповсюдженим, як і системи декларування, упроваджені для виконавчих і законодавчих органів; b) які цілі найчастіше переслідуються в контексті запровадження декларування статків стосовно суддів; с) чи регулюються системи декларування стосовно суддів тими ж правовими нормами, що застосовуються до інших осіб; d) у чому полягають особливості інституційного механізму декларування для суддів; е) чи є уповноважені інститути однаковими для всіх гілок влади або відповідні повноваження покладаються на специфічну інституцію, інтегровану в національну систему судових органів; f) на кого покладається вимога стосовно декларування статків у межах судових органів; g) які категорії інформації 
найчастіше висвітлюються в деклараціях; h) чи є декларації суддів доступними для громадськості; i) чи є декларації такими, що підлягають перевірці та моніторингу; j) чи передбачаються в національному законодавстві санкції за недотримання зобов'язання з декларування статків або подання недостовірної інформації, тощо [1, с. 2].

Зважаючи на вказане, це дослідження зосереджене на чотирьох ключових проблемах: а) запровадження системи декларування для суддів як специфічних суб'єктів b) порядок оприлюднення й режим доступу до інформації, що міститься в деклараціях суддів; с) система інститутів, уповноважених здійснювати збір і перевірку декларацій суддів; d) юридична відповідальність за неподання декларацій або зазначення недостовірної інформації в них.

У державах, які запровадили систему декларування статків, можна виокремити два підходи до визначення кола суб'єктів, на яких покладаються відповідні зобов'язання: a) обов'язок оприлюднювати інформацію стосовно наявного майна й доходів покладається на всіх державних службовців; b) адресатами зобов'язань щодо декларування майна й доходів є обмежене коло державних службовців, зважаючи на належність до конкретної гілки влади (наприклад, тільки посадові особи виконавчих органів влади), спосіб призначення на посаду, специфіку повноважень, розмір винагороди за виконання професійної діяльності, місця певної посади в ієрархії органів державної влади або поєднання відповідних критеріїв [1, с. 4].

За результатами дослідження законодавства 158 держав, здійсненого експертами Світового банку, виявлено, що в $56 \%$ національних правопорядків судді та прокурори зобов'язані декларувати власні майно й доходи (для суддів вищих судових інстанцій відповідний показник дещо вищий і становить $59 \%$; водночас показники обов'язкового декларування статків для депутатів національних парламентів і членів урядів становлять $90 \%$ і 92\% відповідно) [7, с. 20].

Ініційований 1 січня 2012 р. Групою держав проти корупції (Group of States against Corruption - GRECO) четвертий раунд оцінювання показників упровадження антикорупційних ініціатив у державах-учасницях (нині 49), присвячений запобіганню корупції серед членів парламентів, суддів і прокурорів, дав змогу виявити загальні тенденції стосовно впровадження системи розкриття інформації щодо майна суддів у досліджуваних правопорядках. Так, окремі держави-учасниці не покладають на суддів зобов'язання стосовно деклару- вання доходів (крім ситуацій неплатоспроможності або позасудової діяльності судді), інші ж вимагають разове подання декларацій у межах процедури призначення на посаду судді або відзначаються існуванням системи декларування статків усіма посадовими особами, включаю суддів і членів їхніх сімей. В останньому випадку моніторинг оприлюдненої інформації уповноваженими органами має визначатися високим ступенем надійності. Крім того, на думку GRECO, криміналізації мають підлягати зазначення неправдивої інформації в деклараціях суб'єктами, на яких покладаються відповідні зобов'язання.

Примітно, що GRECO дотримується досить прагматичного підходу стосовно запровадження системи обов'язкового декларування статків суддями. Так, якщо ті чи інші національні правопорядки відзначаються низькими показниками корупції й значною довірою суспільства до судової влади, упровадження відповідних механізмів не вважається обов'язковим [8, с. 21].

Відтак переважно в державах, що визначаються значними показниками розвитку й стабільності функціонування демократичних інститутів, законодавчі вимоги стосовно обов'язкового декларування статків суддями відсутні. До таких держав належать Австрія [9, para. 123], Бельгія [10, para. 115], Кіпр [11, para. 152], Сполучене Королівство [12, para 132], Франція [13, para. 102-105], Мальта [14, с. 110], Швейцарія [15, para. 172], Ісландія [16, para. 110], Люксембург [17, para. 130], Данія [18, para. 109], Нідерланди [19, para. 112], Іспанія [20, para. 109], Німеччина [21, para. 173], Швеція [22, para. 128].

У цьому контексті варто зазначити, що в більшості згаданих держав на суддів розповсюджуються механізми фіскального контролю, які застосовуються до всіх платників податків (Кіпр, Мальта, Швейцарія, Люксембург тощо).

Водночас судді є повноцінними суб'єктами декларування статків у Болгарії, Албанії, Словаччині, Польщі, Естонії, Чорногорії, Латвії, Хорватії, Грузії, Азербайджані (тобто вказаний механізм переважно притаманний молодим демократіям), Норвегії та США.

Відповідні держави залежно від специфіки комплексу правових норм, якими встановлюється зобов'язання суддів декларувати власні статки, можна розподілити на дві групи: а) держави, у яких діють загальні для всіх, включаючи суддів, правила стосовно декларування майна та доходів (Албанія [23, с. 6], Естонія [24, para. 132], Чорногорія [25, para. 100], Латвія [26, para. 59], Грузія 
[27, para. 120], Азербайджан [28, para. 74], США [29, para. 197] - щодо суддів системи федеральних судів); b) держави, у яких вимоги щодо декларування статків суддів базуються на профільних «судових» законодавчих актах, отже, відрізняються від вимог, що висуваються до інших державних службовців у відповідній сфері (Болгарія [30, para. 65], Норвегія [31, para. 142], Польща [32, para. 140], Хорватія [33]).

Досить нетиповим на загальному тлі $\epsilon$ підхід, утілений у законодавстві Португалії, відповідно до якого суб'єктами декларування статків є тільки судді Конституційного Суду, які прирівнюються до «політичних» посадових осіб (political officeholders) [34, para. 128].

У досліджуваних державах правила, які стосуються регулярності подання декларацій, загалом співпадають. Так, судді подають декларації при призначенні або обранні на посаду, виході у відставку/звільненні з посади, протягом певного, установленого законом, строку після виходу у відставку, у разі суттєвих змін фінансового стану та на щорічній основі протягом усього строку повноважень.

Вимоги ж стосовно інформації, яка повинна відображатися в деклараціях суддів, не є однорідними. Так, разом із загальними для всіх національних правопорядків вимогами, відповідно до яких у деклараціях зазначається інформація щодо нерухомого та рухомого майна, загальної суми доходів, отриманих протягом звітного періоду тощо, в окремих державах існують специфічні правила щодо змісту відповідних декларацій. У деклараціях можуть не вказуватися дані стосовно майна/ фінансових зобов'язань, вартість/сума яких не перевищує встановленої законом граничної межі (наприклад, у Словаччині EUR 6600 для нерухомого та рухомого майна [35, para. 93], боргів і подарунків [36, para. 39]; Польща - еквівалент EUR 2423 для нерухомого майна та зобов'язань [32, para. 140]; Естонія - EUR 3500 для зобов'язань [24, para. 56]), повинні зазначатися дані щодо участі в адміністративних і контрольних органах підприємств і неурядових організацій (Болгарія [30, para. 65]), володіння корпоративними правами (зокрема в Норвегії, якщо вартість акцій перевищує еквівалент EUR 24578 або у володінні знаходяться понад 10\% акцій компанії [31, para 144]) тощо.

За загальним правилом, декларації суддів мають містити інформацію стосовно майна й доходів чоловіка/дружини та дітей, що проживають разом із декларантом, а також близьких родичів.
У контексті визначення загальних стандартів стосовно порядку оприлюднення й режиму доступу до інформації, що міститься в деклараціях державних службовців, неможливо констатувати існування однорідного підходу. 3 одного боку, забезпечення загального доступу до відповідної інформації може сприяти зміцненню довіри громадськості до представників органів державної влади, а також слугувати підвищенню ефективності систем моніторингу та контролю, зважаючи на залучення до цього процесу широкого кола зацікавлених осіб, зокрема представників неурядових організацій і засобів масової інформації [1, с. 7-8]. 3 іншого боку, обмеження доступу до декларованої інформації може бути виправдане необхідністю забезпечення права на повагу до приватного життя, а також запобіганням будь-яким протиправним посяганням на життя й майно декларанта та членів його сім'ї. Особливої гостроти дискусія із цього питання набуває стосовно суддів, з огляду на їхній спеціальний статус i гарантії незалежності під час здійснення ними правосуддя, а також заборону будьякого впливу з боку третіх осіб. Наприклад, у Сербії з публічного доступу вилучаються декларації суддів, що розглядають справи, пов'язані 3 організованою злочинністю, корупційними правопорушеннями та іншими тяжкими злочинами [37, с. 3].

Відповідно до звіту Міжнародної асоціації суддів, запровадження публічних реєстрів декларацій суддів може бути виправдане, лише якщо це обумовлюється конкретними обставинами, зокрема у випадках, коли існують обгрунтовані підозри стосовно вчинення правопорушення конкретним суддею або на тлі загальної дисфункції національної системи правосуддя, а відповідні заходи мають бути пропорційними чинній ситуації [38, с. 8].

Водночас у тих державах, де декларації підлягають оприлюдненню, дані стосовно судді підлягають попередньому редагуванню шляхом вилучення з них будь-якої чутливої інформації (наприклад, адреси помешкання, номерного знака автомобіля, ідентифікаційного коду, реквізитів банківських рахунків тощо) [37, с. 3].

Держави, законодавством яких установлено вимогу декларування суддями майна та доходів, за критерієм відкритості доступу до декларацій можна умовно поділити на дві групи: а) держави з відкритим публічним доступом до відповідної інформації та b) держави, які тією чи іншою мірою такий доступ обмежують.

Так, у більшості досліджуваних держав - Норвегії [31, para. 143], Словаччині 
[35, para. 93], Польщі [39, para. 13], Естонії [24, para. 132], Чорногорії [25, para. 52], Латвії [26, para. 131], Хорватії [40, para. 26], Грузії [27, para. 60] - декларації суддів знаходяться у відкритому доступі та зазвичай публікуються на спеціальних онлайн платформах (офіційних сайтах).

На противагу цій практиці, в Азербайджані інформація, відображена в деклараціях про статки суддів, має конфіденційний характер і не підлягає оприлюдненню [28, para. 74], а в США [29, para. 199], Польщі (до 2017 року) [32, para. 141], Хорватії (до 2018 року) [33, para. 116] доступ до відповідної інформації надається (надавався) на підставі мотивованих запитів зацікавлених осіб.

При цьому, відповідно до естонського [24, para. 132] й латвійського [26, para. 130] законодавства, з публічного доступу вилучається інформація стосовно третіх осіб, що є членами сім'ї, родичами, контрагентами, кредиторами чи боржниками декларанта.

Практика держав стосовно регламентації діяльності спеціальних органів, покликаних здійснювати збір, аналіз і перевірку декларацій суддів, а так само прямо чи опосередковано брати участь у притягненні осіб до відповідальності за порушення правил декларування, також не є однорідною, що насамперед зумовлено унікальним історичним досвідом, особливостями національних правових систем, специфікою організації та функціонування судової влади.

Так, в окремих державах декларації суддів підпадають під контроль з боку органів, що здійснюють моніторингові функції стосовно й інших державних службовців (наприклад, податкові служби або антикорупційні коміciï). В інших державах перевірка майнових декларацій судів здійснюється органами, безпосередньо інтегрованими в структуру національної судової системи. Останній підхід систематично зазнає критики, що спирається на низку аргументів, зокрема вказівку на відсутність у представників судової влади належної компетентності щодо надання фахової оцінки фінансової звітності, нестачу належних матеріальних, технічних і людських ресурсів для ефективного виконання релевантних функцій, на противагу вже чинним податковим та антикорупційним органам, а також наявність потенційних ризиків невиявлення ймовірних порушень відповідних процедур через презюмовану корпоративну солідарність між особами, уповноваженими здійснювати перевірку декларацій, і суддями-декларантами [37, с. 3].

Видається доцільним, зважаючи на особливості національних інституційних механізмів у досліджуваній сфері, розподілити держави за цим критерієм на три групи: а) держави, у яких акумулюванням і перевіркою декларацій суддів опікуються органи суддівського врядування, їх спеціальні підрозділи; b) держави, у яких отримання, збір та оцінка декларацій суддів здійснюється разом із деклараціями інших державних службовців єдиним контролюючим антикорупційним i/або податковим органом; с) держави, у яких процес збору і моніторингу декларацій здійснюється спільними зусиллями органів судового врядування та антикорупційними, податковими або іншими уповноваженими органами.

До першої групи належать Болгарія, де перевірка доброчесності й декларацій стосовно майна та доходів суддів здійснюється Інспекторатом Вищої ради правосуддя, наділеним широкими повноваженнями стосовно збору будь-якої релевантної інформації з державних реєстрів і баз даних [30, para. 67].

При цьому, незважаючи на те що Інспекторат інтегровано в структуру Вищої ради правосуддя, Генеральний інспектор і десять інспекторів (увесь склад органу) є формально та функціонально незалежними й обираються Парламентом. Однак такий підхід до формування особового складу зазнає нищівної критики як на національному рівні, так i $з$ боку інституцій Європейського Союзу. Нині пропонується передати повноваження щодо обрання членів Інспекторату безпосередньо вищим судовими органами або 3'їзду суддів [41].

У Словаччині еквівалентні функції виконує спеціальна Комісія з контролю майнових декларацій суддів, інтегрована в структуру Ради правосуддя [36, para. 45].

Функції щодо збору й оприлюднення декларацій суддів у Норвегії здійснюється Судовою адміністрацією (Norwegian Courts Administration), яка, однак, не здійснює їх систематичну перевірку (система побудована на довірі до суддів, а перевірка здійснюється в конкретних випадках, якщо є обгрунтована підозра щодо вчинення порушення) [31, para. 145-146].

До другої групи держав належать Естонія, де збір і перевірка декларацій здійснюється Парламентським антикорупційним комітетом [24, para. 132]; Чорногорія, у якій перевірка декларацій посадових осіб, включаючи суддів, реалізується Комісією із запобігання конфлікту інтересів [25, para. 54]; Латвія - Бюро щодо запобігання корупції та боротьби з корупцією й Державна податкова служба [26, para. 135]; Грузія, де Бюро державної служби є інституцією виключно уповноваженою здійснювати збір та оцінку майнових декларацій державних службовців 
[27, para. 68] (з 2017 року в його структурі функціонує Департамент з моніторингу майнових декларацій) [42, para. 82].

Польща та Хорватія відзначаються змішаною системою контролюючих органів і відтак належать до третьої групи держав.

У Польщі збір і первинна оцінка декларацій суддів здійснюється спеціальними комісіями, створеними в межах апеляційних судів (складаються 3 голови та п'яти суддів, які обираються зі складу суду), при цьому перевірка декларацій голів апеляційних судів здійснюється Фіскальною комісією Національної ради правосуддя. Водночас перехресна перевірка здійснюється податковими органами. Останні у випадку виникнення сумнівів щодо достовірності інформації, указаної в декларації, можуть ініціювати процедуру наступного моніторингу, здійснювану Центральним антикорупційним бюро [32, para. 147, 149-150, 153].

У свою чергу, у Хорватії перевірка декларацій суддів здійснюється Державною радою правосуддя. Паралельно моніторинг стосовно достовірності відповідних даних забезпечується податковими органами. Майнові декларації всіх інших посадових осіб перевіряються незалежним та автономним органом - Комісією щодо запобігання конфлікту інтересів [33, para. 117].

Притягнення до юридичної відповідальності часто сприймається як дієвий інструмент і вирішальний засіб досягнення мети системи декларування державними службовцями власних статків, фундаментальним аспектом забезпечення ï̈ високої ефективності. Водночас держави, розробляючи механізм притягнення до відповідальності винних осіб і встановлюючи відповідні санкції, повинні чітко усвідомлювати їх цільове призначення, забезпечувати послідовність i сталість i гарантувати пропорційність їх застосування.

У досліджуваних державах юридична відповідальність стосовно декларування переважно передбачена за порушення процедурних (неподання чи несвоєчасне подання декларацій) і «якісних» (точність, повнота й достовірність даних) вимог. При цьому все більше держав тяжіють до практики криміналізації вказаних порушень.

Так, у Польщі з 2016 року введено кримінальну відповідальність за умисне надання державними службовцями, зокрема й суддями, недостовірних даних у деклараціях, а неподання чи несвоєчасне подання декларацій тягне за собою дисциплінарну відповідальність, що в окремих випадках призводитиме до звільнення з посади [32, para. 157; 43, para. 29].
В Естонії поряд із дисциплінарною відповідальністю особи, які не дотримали обов'язку декларування або подали недостовірні дані в деклараціях, нестимуть кримінальну відповідальність [24, para. 142].

У свою чергу, у Грузії кримінальна відповідальність передбачена за неподання декларації й унесення в неї неповних чи недостовірних даних, а за несвоєчасне направлення декларацій особа може бути притягнута до адміністративної відповідальності [27, para. 134].

Водночас, відповідно до законодавства Латвії, за такі порушення особа може бути притягнута тільки до адміністративної відповідальності [26, para. 136], у Норвегії - до дисциплінарної чи адміністративної відповідальності (залежно від ступеня вини, умислу, негативних наслідків таких дій тощо) [31, para. 148], а в Словаччині [35, para. 97] і Хорватії [33, para. 117] - тільки до дисциплінарної відповідальності.

\section{Висновки}

Світова практика побудови систем декларування статків суддями є дуже неоднорідною. У державах, яким притаманні значні показники розвитку й стабільності функціонування демократичних інститутів, спеціальні законодавчі вимоги стосовно обов'язкового декларування статків суддями та відповідне інституційне забезпечення переважно відсутні (Австрія Бельгія, Франція, Швейцарія, Нідерланди, Німеччина тощо). Водночас у більшості із цих національних правопорядків на суддів розповсюджуються механізми фіскального контролю, які застосовуються до всіх платників податків.

Держави ж, у яких на суддів покладено обов'язок декларувати власні статки, можна розподілити на дві групи: а) ті, у яких діють загальні для всіх, включаючи суддів, правила декларування майна та доходів; b) ті, у яких вимоги щодо декларування статків суддів базуються на профільних «судових» законодавчих актах, отже, відрізняються від вимог, що висуваються до інших посадових осіб у відповідній сфері.

Щодо інформації, яка повинна бути внесена до декларацій, в окремих державах запроваджено специфічні обмеження та винятки. Так, наприклад, можуть не вказуватися дані стосовно майна/фінансових зобов'язань, вартість/сума яких не перевищує встановленої законом граничної межі, повинні зазначатися дані щодо участі в адміністративних і контрольних органах підприємств і неурядових організацій, володіння корпоративними правами тощо. 
у більшості досліджуваних держав декларації суддів знаходяться у відкритому доступі та зазвичай публікуються на спеціальних онлайн платформах. На противагу цій практиці, в Азербайджані інформація, відображена в деклараціях про статки суддів, має конфіденційний характер і не підлягає оприлюдненню, а в США, Польщі (до 2017 року), Хорватії (до 2018 року) доступ до відповідної інформації надається (надавався) на підставі мотивованих запитів зацікавлених осіб.

Зважаючи на особливості національних інституційних механізмів у досліджуваній сфері, видається можливим розподілити досліджувані юрисдикції на три групи: а) держави, у яких акумулюванням і перевіркою декларацій суддів опікуються органи суддівського врядування, їх спеціальні підрозділи; b) держави, у яких отримання, збір та оцінка декларацій суддів здійснюються разом із деклараціями інших державних службовців єдиним контролюючим антикорупційним і/ або податковим органом; с) держави, у яких процес збору та моніторингу декларацій здійснюється спільними зусиллями органів судового врядування й антикорупційними, податковими або іншими уповноваженими органами.

У досліджуваних державах юридична відповідальність стосовно декларування переважно передбачена за порушення процедурних (неподання декларацій чи несвоєчасне подання) і «якісних» вимог (точність, повнота та достовірність даних). При цьому все більше держав тяжіють до практики криміналізації вказаних порушень.

\section{Список використаних джерел:}

1. Launch of the Global Judicial Integrity Network. Financial Disclosure by Judges Session. Monday April 9th 2018, United Nations Vienna. URL: https://www.unodc.org/documents/ji/ discussion_guides/Financial_Disclosure_by_ Judges.pdf (дата звернення: 05.03.2021).

2. Конвенція Організації Об'єднаних Націй проти корупції, 2003. URL: https://zakon.rada. gov.ua/laws/show/995_c16\#Text (дата звернення: 05.03.2021).

3. African Union Convention on Preventing and Combating Corruption, 01.07.2003. URL: https:// au.int/en/treaties/african-union-conventionpreventing-and-combating-corruption (дата звернення: 05.03.2021).

4. Arab Anti-Corruption Convention, 21.12.2010. URL: https://star.worldbank.org/sites/star/files/ Arab-Convention-Against-Corruption.pdf (дата звернення: 05.03.2021).

5. Inter-American Conventions against Corruption, 29.03.1996. URL: http://www.oas.org/
en/sla/dil/docs/inter_american_treaties_B-58_

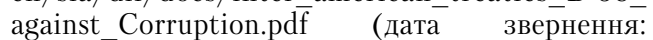
05.03.2021)

6. CCJE Opinion No. 21 (2018) 'Preventing Corruption Among Judges'. URL: https://www. vkksu.gov.ua/userfiles/doc/perelik-dokumentiv/ vys_21.pdf (дата звернення: 05.03.2021).

7. Rossi Ivana M., Pop Laura, Berger Tammar. Getting the Full Picture on Public Officials: A How-To Guide for Effective Financial Disclosure. 2017. 125 c. URL: https://star.worldbank.org/ sites/star/files/getting-the-full-picture-on-publicofficials-how-to-guide.pdf (дата звернення: 05.03.2021).

8. Corruption Prevention: Members of Parliament, Judges and Prosecutors. Conclusions and Trends. GRECO, 2017. URL: https://rm.coe. int/corruption-prevention-members-of-parliamentjudges-and-prosecutors-con/16807638e7 ～(дата звернення: 05.03.2021).

9. GRECO Evaluation Report. Austria. GrecoEval4Rep(2016)1 of 21.10.2016.

10. GRECO Evaluation Report. Belgium. Greco Eval IV Rep (2013) 8E of 28.03.2014.

11. GRECO Evaluation Report. Cyprus. GrecoEval4Rep(2017)7 of 01.07.2016.

12. GRECO Evaluation Report. United Kingdom. Greco Eval IV Rep (2012) 2E of 19.10.2012.

13. GRECO Evaluation Report. France. Greco Eval IV Rep (2013) 3E of 06.12.2013.

14. GRECO Evaluation Report. Malta. Greco Eval IV Rep (2014) 4E of 12.12.2014.

15. GRECO Evaluation Report. Switzerland. GrecoEval4Rep(2016)5 of 02.12.2016.

16. GRECO Evaluation Report. Iceland. Greco Eval IV Rep (2012) 8E of 22.03.2013.

17. GRECO Evaluation Report. Luxembourg. Greco Eval IV Rep (2012) 9E of 21.06.2013.

18. GRECO Evaluation Report. Denmark.

Greco Eval IV Rep (2013) 6E of 28.032014.

19. GRECO Evaluation Report. Netherlands.

Greco Eval IV Rep (2012) 7E of 21.06.2013.

20. GRECO Evaluation Report. Spain. Greco

Eval IV Rep (2013) 5E of 06.12.2013.

21. GRECO Evaluation Report. Germany. Greco Eval IV Rep (2014) of 10.10.2014.

22. GRECO Evaluation Report. Sweden. Greco Eval IV Rep (2013) 1E of 18.10.2013.

23. Analysis of the System of Asset Declarations of Constitutional Court Judges in Albania. Balkan Investigative Reporting Network in Albania. Tirana, 2017. 44 c. URL: https://birn.eu.com/ wp-content/uploads/2017/07/Asset_DeclarationsConstitutional_Court_Judges.pdf (дата звернення: 05.03.2021)

24. GRECO Evaluation Report. Estonia. Greco Eval IV Rep (2012) 5E of 07.12.2012.

25. GRECO Evaluation Report. Montenegro. Greco Eval IV Rep (2014) 6E of 19.06.2015. 26. GRECO Evaluation Report. Latvia. Greco Eval IV Rep (2012) 3E of 07.12.2012.

27. GRECO Evaluation Report. Georgia. GrecoEval4Rep(2016)3 of 02.12.2016. 
28. GRECO Evaluation Report. Azerbaijan. Greco Eval IV Rep (2014) 2E of 10.10.2014.

29. GRECO Evaluation Report. United States of America. GrecoEval4Rep(2016)10 of 02.12.2016.

30. GRECO Compliance Report. Bulgaria GrecoRC4(2017)9 of 23.06.2017.

31. GRECO Evaluation Report. Norway. Greco Eval IV Rep (2013) 10E of 20.06.2014.

32. GRECO Evaluation Report. Poland. Greco Eval IV Rep (2012) 4E of 19.10.2012.

33. GRECO Evaluation Report. Croatia. Greco Eval IV Rep (2013) 7 of 20.06.2014.

34. GRECO Evaluation Report. Portugal. Greco Eval IV Rep (2015) 5E of 04.12.2015.

35. GRECO Evaluation Report. Slovak Republic. Greco Eval IV Rep (2013) 2E of 18.10.2013.

36. GRECO Addendum to the Second Compliance Report. Slovak Republic. GrecoRC4(2019)8 of 22.03.2019.

37. The case for asset declarations in the judiciary: Identifying illicit enrichment and conflicts of interests. U4 Brief, 2014. 5 p. URL: https:// www.cmi.no/publications/5136-the-case-for-assetdeclarations-in-the-judiciary (дата звернення: 05.03.2021).
38. Report of the IAJ 1st Study Commission on measures to promote integrity and combat corruption within the judiciary. International Association of Judges Report. 2016. URL: https://www.ajoa.asn.au/ wp-content/uploads/2015/08/Report-of-the-IAJ1st-Study-Commission-on-measures-to-combatcorruption.pdf (дата звернення: 05.03.2021).

39. GRECO Addendum to the Second Compliance Report. Poland. GrecoRC4(2018)11 of 22.06.2018.

40. GRECO Second Compliance Report. Croatia. GrecoRC4(2018)14 of 07.12.2018.

41. Communication from the Commission to the European Parliament, the Council, the European Economic and Social Committee and the Committee of the Regions. 2020 Rule of Law Report 'The rule of law situation in the European Union'. COM/2020/580 final. Brussels, 30.09.2020. URL: https://eur-lex.europa.eu/legal-content/EN/TXT $/$ ?qid $=1602583951529 \&$ uri $=$ CELEX\%3A5202 0DC0580 (дата звернення: 05.03.2021).

42. GRECO Compliance Report. Georgia. GrecoRC4(2019)9 of 22.03.2019.

43. GRECO Second Compliance Report, Poland. GrecoRC4(2017)2 of 24.03.2017.

Yana Benedyk, Vasyl Benedyk. A foreign experience of developing the asset declaration systems for judges

The article deals with the foreign experience of establishing judges' asset declarations systems in the national legal systems of particular, mostly European, countries. The attention is concentrated on four main issues: a) an introduction of an asset declaration system for judges considering their specific legal status; b) disclosure of information concerning judges' asset declaration; c) the system of institutions authorized to accumulate and verify judges' asset declarations; d) legal liability for failure to submit declarations or providing false/misleading information. A number of conclusions are made, e.g., there are no legal requirements for the mandatory judges' asset declaration and its appropriate institutional support in countries with significant indicators of the democratic institutions' development and stability; on the other hand, in countries where such an obligation is provided, assets declaring is performed either according to the general rules applicable to all public officials or in line with the rules and procedures which are set by a special law and may differ due to the specific status of judges; in the vast majority of the examined countries, judges' asset declarations are publicly available and usually published online, although in some cases, access to the relevant information may be provided only based on the duly motivated request. Depending on the institutional mechanism's specifics, the examined countries may be divided into three groups: those in which the judicial authorities and their special subdivisions perform the accumulation and verification of judges' asset declarations; in which it is performed by the single supervisory anti-corruption and/or tax body as a part of integral public officials asset declaring system; in which it is performed by the joint efforts of the judicial authorities and anticorruption, tax or other authorized bodies. Furthermore, the vast majority of countries tend to criminalize violation of the asset-declaring rules and procedures by public officials, in general, and judges, in particular.

Key words: state control, asset declarations systems, judges' asset declarations, foreign experience. 